Terr. Atmos. Ocean. Sci., Vol. 17, No. 4, 1009-1026, December 2006

\title{
Complicated Magnetic Mineral Assemblages in Marine Sediments Offshore of Southwestern Taiwan: Possible Influence of Methane Flux on the Early Diagenetic Process
}

\author{
Chorng-Shern Horng ${ }^{1,}{ }^{*}$ and Kuo-Hang Chen ${ }^{1}$
}

(Manuscript received 21 June 2006, in final form 26 September 2006)

\begin{abstract}
In this paper, we present the results of down core variations in magnetic susceptibility and magnetic mineral composition of fifteen piston cores retrieved from the active continental margin offshore of southwestern Taiwan, where a wide distribution of bottom simulating reflectors (BSRs) related to gas hydrate layers has been detected. $X$-ray analysis on magnetic extracts from the cores indicates that detrital magnetite and authigenic greigite, in various proportions, are the dominant magnetic minerals in sediments. Non-magnetic, authigenic pyrite is generally associated with greigite, but it may co-exist with magnetite or may solely occur in sediments. Consequently, the sediment sequences of the fifteen piston cores have complicated magnetic mineral assemblages that result in various magnetic susceptibility profiles. For core segments containing detrital magnetite as the only magnetic mineral, values of magnetic susceptibility are moderate with small variations $\left(8-15 \times 10^{-6} \mathrm{SI}\right)$, which can be regarded as the susceptibility backgrounds for the initially deposited sediments. However, high magnetic susceptibilities relative to the backgrounds were found in core segments where magnetic mineral is enriched in greigite. Magnetic susceptibilities lower than the backgrounds were found in segments where neither magnetite nor greigite were detected. The complicated occurrence of magnetic minerals reveals that their host sediments at different levels have suffered various degrees of early diagenetic process ranging from oxic to anoxic conditions. Due to very low sedimentary organic matter content in the study area, detrital magnetite persisted in sediments that were subjected to
\end{abstract}

\footnotetext{
${ }^{1}$ Institute of Earth Sciences, Academia Sinica, Taipei, Taiwan, ROC

* Corresponding author address: Dr. Chorng-Shern Horng, Institute of Earth Sciences, Academia Sinica, Taipei, Taiwan, ROC; E-mail: cshorng@earth.sinica.edu.tw
} 
initially oxic (or sub-oxic) conditions. However, the sedimentary organic matter is apparently insufficient for providing reducing environments for the formation or enrichment of authigenic iron sulfides. Instead, we propose that gaseous methane derived from gas hydrates in deeper sedimentary layers should be the most likely source of extra organic matter. The different flux intensities of this gas either through slow diffusion or rapid venting resulted in various anoxic conditions, which caused the dissolution or survival of magnetite and the formation or enrichment of greigite and pyrite.

(Key words: Magnetite, Greigite, Pyrite, Magnetic susceptibility, Diagenesis, Methane, Gas hydrate, Accretionary wedge)

\section{INTRODUCTION}

Magnetite (or titano-magnetite) is well documented as being the most common magnetic mineral in marine sediments (Løvlie et al. 1971; Opdyke 1972). Magnetite in marine sediments is sourced mainly from detritus derived from river transport, winds and ices, or from microbial organisms in sediments (Kirschvink and Chang 1984). When detritus is deposited on the seafloor, detrital magnetite, under anoxic conditions, undergoes a reduction process and thus progressive dissolution (Canfield and Berner 1987; Leslie et al. 1990). This dissolution is a complicated biogeochemical reaction that occurs during the early diagenetic process which includes oxidation of organic matter $\left(\mathrm{CH}_{2} \mathrm{O}\right.$, as a generic form of organic matter) and reduction of sulfate $\left(\mathrm{SO}_{4}^{2-}\right)$ in pore water to form hydrogen sulfide $\left(\mathrm{H}_{2} \mathrm{~S}\right)$ via bacterial activities (i.e., $\left.\mathrm{SO}_{4}^{2-}+2 \mathrm{CH}_{2} \mathrm{O} \rightarrow \mathrm{H}_{2} \mathrm{~S}+2 \mathrm{HCO}_{3}^{-}\right)$. During this process, two iron sulfide minerals, i.e., magnetic greigite $\left(\mathrm{Fe}_{3} \mathrm{~S}_{4}\right)$ and non-magnetic pyrite $\left(\mathrm{FeS}_{2}\right)$, may form depending on the concentration of $\mathrm{H}_{2} \mathrm{~S}$ produced and the availability of reactive $\mathrm{Fe}^{2+}$. It is claimed that greigite is a precursor of pyrite, which forms when the production of $\mathrm{H}_{2} \mathrm{~S}$ is low (Goldhaber and Kaplan 1974; Schoonen and Barnes 1991; Wilkin and Barnes 1996). However, if the supply of $\mathrm{SO}_{4}^{2-}$ and $\mathrm{CH}_{2} \mathrm{O}$ is sufficient for the production of high $\mathrm{H}_{2} \mathrm{~S}$ contents, a complete reduction of iron minerals to pyrite would occur. As a result of varying anoxic conditions during early diagenesis, magnetic mineral assemblages in marine sediments may change significantly.

The bottom-simulating reflector (BSR), a prominent seismic reflector from the base of gas-hydrate bearing layers, has been widely detected beneath the seafloor in the accretionary wedge off southwestern Taiwan (Reed et al. 1992; Chi et al. 1998; Schnürle et al. 1999). Gas hydrates are non-stoichiometric solid substances in which an isometric ice $\left(\mathrm{H}_{2} \mathrm{O}\right)$ lattice forms cages (called a clathrate) that incorporate small guest gas molecules (e.g., $\mathrm{CH}_{4}, \mathrm{CO}_{2}$, and $\mathrm{H}_{2} \mathrm{~S}$ ). They are stable at moderate to high pressures (300 - $2000 \mathrm{~m}$ below the seafloor) and low temperatures $\left(0-20^{\circ} \mathrm{C}\right)$. On the basis of a hydrate stability phase diagram (Sloan 1998), it is inferred that solid gas hydrates in marine sediments may exist potentially above the BSR, whereas free gas, composed of $99 \%$ methane $\left(\mathrm{CH}_{4}\right)$, should be confined in layers below the BSR (Liu and Flemings 2006). However, gaseous methane has been commonly found in seawaters and near-surface sediments off southwestern Taiwan (Chen and Tseng 2006; Chuang et al. 2006; Oung et al. 2006; Yang et al. 2006), implying that methane gas is probably migrating from 
deeper sedimentary layers. Once the upward $\mathrm{CH}_{4}$ encounters $\mathrm{SO}_{4}^{2-}$ in pore water, a reaction called anaerobic oxidation of $\mathrm{CH}_{4}$ occurs (Barnes and Goldberg 1976; Borowski et al. 1996), which leads to the production of $\mathrm{H}_{2} \mathrm{~S}$ (i.e., $\mathrm{SO}_{4}^{2-}+\mathrm{CH}_{4} \rightarrow \mathrm{HCO}_{3}^{-}+\mathrm{HS}^{-}+\mathrm{H}_{2} \mathrm{O}$ ) and may therefore cause compositional changes to the magnetic mineral assemblage of sediments (Novosel et al. 2005; Garming et al. 2005).

In order to understand the possible influence of methane gas on magnetic mineralogy in the potential gas hydrate area off southwestern Taiwan, we carried out magnetic susceptibility measurements and magnetic mineral identifications of piston-cored sediments from the study area.

\section{GEOLOGICAL BACKGROUND}

The area studied is located in the Kaoping shelf-slope that is believed to be the northern part of a large accretionary wedge resulting from the collisions of the Philippine Sea Plate with the South China Sea Plate to the south, and the Eurasian Plate to the north (Fig. 1a). The wedge is bounded on the west by a submarine deformation front (Reed et al. 1992; Liu et al. 1997), which is the northward extension of the Manila Trench that became shallower when the subduction of the South China Sea Plate under the Philippine Sea Plate was followed by the collision between the Philippine Sea Plate and the Eurasian Plate along the Chinese continental margin (Fig. 1b). Topographic mapping shows prominent submarine canyons, such as the Penghu, Kaoping and Fangliao, incising the region. Seismic surveys reveal that numerous growing fold-and-thrust structures trending in NNW-SSE and NNE-SSW directions prevail in the active continental margin on the east of the deformation front (Liu et al. 1997). Beneath structure highs, it is common to find BSRs (Reed et al. 1992; Chi et al. 1998; Schnürle et al. 1999; Liu et al. 2006). In addition, mud diapirs are pervasively located in the upper slope of the wedge (Sun and Liu 1993).

As shown in Fig. 1b, several offshore fold-and-thrust structures extend inland to the coastal plain and foothills of Taiwan. Along these structural features are active mud volcanoes that outgas methane as a dominant constituent (Shih 1967; Yang et al. 2004). The lithology of rocks exposed on the foothills of southwestern Taiwan is characterized by extraordinarily thick ( $>3000 \mathrm{~m}$ ) massive mudstones and muddy siltstones. The sediments of which were first deposited in an ancient foreland basin during the Plio-Pleistocene. In the mudstone sequences, as indicated by the representative EJC section in Fig. 1b, widespread distribution of greigite has been reported in rocks for an area of $600-\mathrm{km}^{2}$ (Horng et al. 1992, 1998; Torii et al. 1996). Coral reef limestones, overlying the mudstones, crop out on the local topographic highs that are closely linked to thrust faulting (Gong et al. 1996). Methane-related authigenic carbonates, including cold-seep carbonates and carbonate chimneys, have been recently discovered between the boundary of the mudstones and limestones (Wang et al. 2006).

\section{SAMPLING \& METHODS}

Sediments for the present study were taken from the second piston cores of fifteen sampling stations (Fig. 1b), which were retrieved from the area between the Penghu and Kaoping 

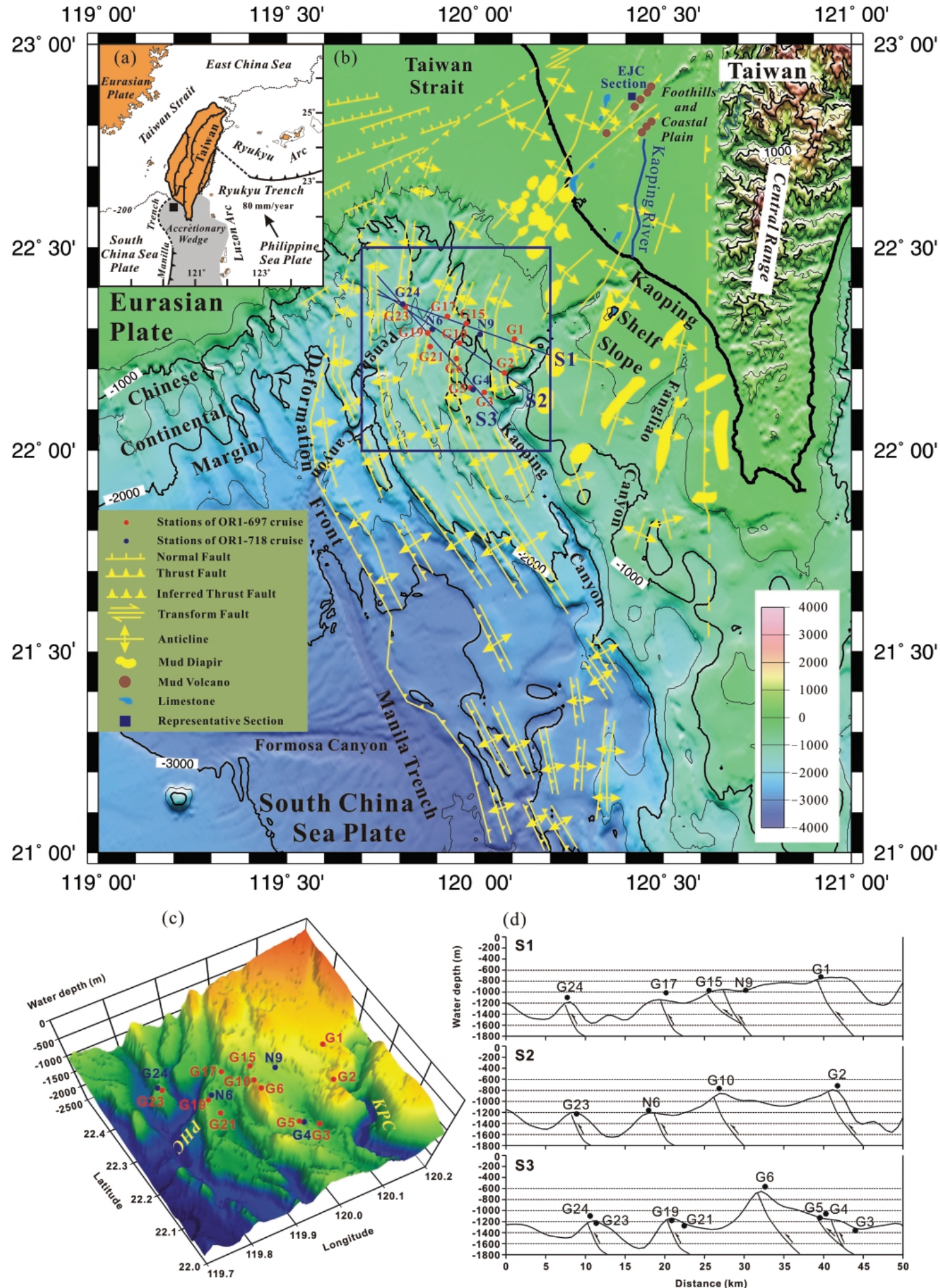

(d)

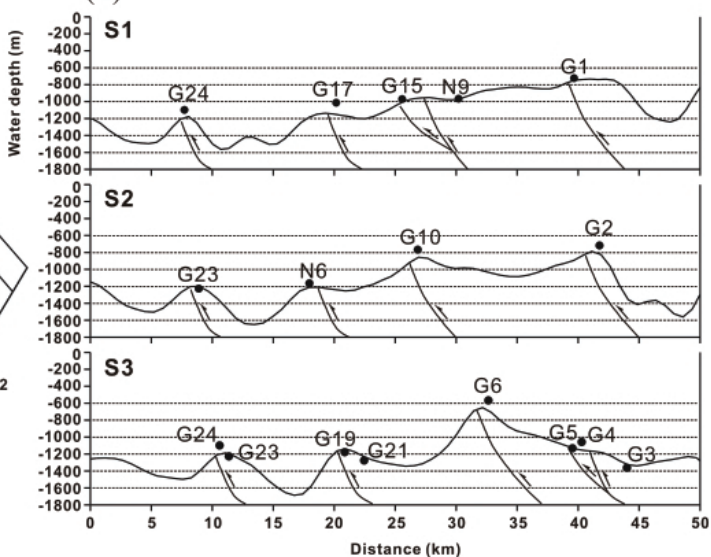


submarine canyons of the active continental margin during two cruises, OR1-697 and OR1-718, by the Taiwanese $R V$ Ocean Researcher- 1 in 2003 and 2004, respectively. Figure 1c illustrates detailed three-dimensional topography for the block region in Fig. 1b, covering the sampling stations. Three line sections along S1, S2 and S3 near the sites are shown in Fig. 1d. Note that stations G1, G2, G6, G10, G19, G23, and G24 are located at topographic highs, while others are close to or in the topographic lows.

The piston cores, having diameters of $6 \mathrm{~cm}$, were marked with a reference line for their orientation and then cut into between 1 to 7 sections, depending on their original lengths $(0.55-5.29 \mathrm{~m})$. After splitting the cores lengthwise into halves along the reference line, description and photographing of the cores commenced. In terms of lithology, the cores are mainly composed of dark gray fine-grained mud, with scattered occurrence of small pits, hollows, black spots and laminations. Some of the cores smelt of $\mathrm{H}_{2} \mathrm{~S}$ upon splitting. Detailed information of all fifteen cores is shown in Table 1 and some selected photos are shown in Fig. 2.

Stiff, transparent, plastic u-shaped tubes, or so-called u-channels, of about $4 \mathrm{~cm}^{2}$ in cross section were cut into sections of the same length as the core sections, and were then pushed upside-down into the flat face of working half cores (see Weeks et al. 1993 for details). Monofilament fishing line was then used to free the u-channels and their sediment samples from the core. Once free, the u-channels were covered with a tight-fitting cap, and the ends were sealed to prevent desiccation of the samples. For magnetic extraction, a suitable amount of sediments from different core intervals were taken.

Continuous measurements of magnetic susceptibility on cores were conducted on the uchannels at 1-cm intervals with an ASC automated core analysis system. Because of end effects, the magnetic susceptibility values at both ends of the u-channels $(\mathrm{ca} .4 \mathrm{~cm}$ ) are abnormally low

Fig. 1. (a) Tectonic setting of Taiwan. The accretionary wedge, resulting from the collision between the Philippine Sea Plate with the South China Sea Plate to the south and the Eurasian Plate to the north, is shown in light gray (after Reed et al. 1992). Black square indicates the study area. (b) A topographic and structural map of offshore and inland southwestern Taiwan (after Sun and Liu 1993; Liu et al. 1997). Core stations from the cruises of OR1-697 and OR1-718 are located in the area between the Penghu and Kaoping submarine canyons of the active continental margin where numerous fold-and-thrust growing structures were found. See text for the detailed explanations of the figure. (c) A detailed three-dimensional topography for the block region in (b), covering the 15 sampling stations. PHC and KPC: Penghu and Kaoping submarine canyons, respectively. (d) Three line sections along S1, S2, and S3 in the block region in (b), showing a two-dimensional topography near the core stations. Growing thrust faults are inferred beneath the topographic highs (see Discussion). 
Table 1. Information for the cores from the cruises of OR1-697 and OR1-718.

\begin{tabular}{|c|c|c|c|c|c|c|}
\hline \multirow{2}{*}{$\begin{array}{l}\text { Core } \\
\text { Station }\end{array}$} & \multirow{2}{*}{$\begin{array}{l}\text { Core } \\
\text { No. }\end{array}$} & \multicolumn{2}{|c|}{ Location } & \multirow{2}{*}{$\begin{array}{l}\text { Water } \\
\text { Depth }(m)\end{array}$} & \multirow{2}{*}{$\begin{array}{l}\text { Core } \\
\text { Length }(\mathrm{cm})\end{array}$} & \multirow{2}{*}{$\begin{array}{c}\text { Core } \\
\text { Description }^{(3)}\end{array}$} \\
\hline & & Lat. $\left({ }^{\circ} \mathrm{N}\right)$ & Long. $\left({ }^{\circ} \mathrm{E}\right)$ & & & \\
\hline \multicolumn{7}{|c|}{ Cruise OR1-697: } \\
\hline G1 & P2 & $22^{\circ} 16.47^{\prime}$ & $120^{\circ} 06.34^{\prime}$ & 724 & $225[3]$ & $\begin{array}{l}0-5 \mathrm{~cm} \text { : void }{ }^{(4)} ; 5-75 \mathrm{~cm} \text { : olive gray muds; } 75-225 \mathrm{~cm} \text { : } \\
\text { homogeneous dark gray muds; } 5-30 \mathrm{~cm} \text { : with fine sub- } \\
\text { horizontal burrows; } 50-52 \mathrm{~cm} \text { : black patch; } 75-225 \mathrm{~cm} \text { : } \\
\text { with fine black laminations (Fig. } 2 \mathrm{a}, \mathrm{b} \text { ). }\end{array}$ \\
\hline G2 & $\mathrm{P} 2$ & $22^{\circ} 11.48^{\prime}$ & $120^{\circ} 04.70^{\prime}$ & 718 & $55[1]$ & $\begin{array}{l}0-7 \mathrm{~cm} \text { : sediments disturbed and not fully filled; } 7-55 \\
\mathrm{~cm} \text { : homogeneous dark gray muds, with fine pits and } \\
\text { black spots (Fig. 2c). }\end{array}$ \\
\hline G3 & P2 & $22^{\circ} 08.57^{\prime}$ & $120^{\circ} 01.55^{\prime}$ & 1363 & $308[4]$ & $\begin{array}{l}0-7 \mathrm{~cm}, 75-78 \mathrm{~cm}, 150-152 \mathrm{~cm} \text { : void; The entire core is } \\
\text { composed of dark gray muds with pits, burrows, and } \\
\text { black spots; black laminations at intervals of } 7-19 \mathrm{~cm} \text {, } \\
242-251 \mathrm{~cm}, 262-265 \mathrm{~cm}, 274-278 \mathrm{~cm} \text { (Fig. } 2 \mathrm{~d} \text { ). }\end{array}$ \\
\hline G5 & P2 & $22^{\circ} 09.22^{\prime}$ & $119^{\circ} 59.26^{\prime}$ & 1132 & $295[4]$ & $\begin{array}{l}0-3 \mathrm{~cm}, 150-152 \mathrm{~cm}, 225-239 \mathrm{~cm} \text { : void; The dark gray } \\
\text { sediments were mottled extensively by black; It is com- } \\
\text { posed of silty muds with an enrichment of foraminifera } \\
\text { somewhere (Fig. } 2 \mathrm{e}, \mathrm{f} \text { ). }\end{array}$ \\
\hline G6 & P2 & $22^{\circ} 13.57^{\prime}$ & $119^{\circ} 57.07^{\prime}$ & 567 & $57[1]$ & $\begin{array}{l}0-22 \mathrm{~cm} \text { : sediments are very soupy and void; } 22-57 \mathrm{~cm} \text { : } \\
\text { dark gray muds with big hollows and small pits (Fig. } 2 \mathrm{~g} \text { ). }\end{array}$ \\
\hline G10 & $\mathrm{P} 2$ & $22^{\circ} 15.82^{\prime}$ & $119^{\circ} 57.49^{\prime}$ & 767 & $97[1]$ & 0-97 cm: homogeneous dark gray muds with small pits. \\
\hline G15 & $\mathrm{P} 2$ & $22^{\circ} 18.72^{\prime}$ & $119^{\circ} 58.62^{\prime}$ & 970 & $182[2]$ & $\begin{array}{l}0-9 \mathrm{~cm} \text { : void; } 9-50 \mathrm{~cm} \text { : gray muds mottled by black; } \\
50-70 \mathrm{~cm} \text { : dark gray muds; } 70-145 \mathrm{~cm} \text { : homogeneous } \\
\text { gray muds; } 145-182 \mathrm{~cm} \text { : dark gray muds with small pits. }\end{array}$ \\
\hline G17 & $\mathrm{P} 2$ & $22^{\circ} 19.81^{\prime}$ & $119^{\circ} 55.64^{\prime}$ & 1013 & $114[1]$ & $\begin{array}{l}0-3 \mathrm{~cm} \text { : void; } 3-114 \mathrm{~cm} \text { : homogeneous dark gray muds } \\
\text { with pits and black spots. }\end{array}$ \\
\hline G19 & $\mathrm{P} 2$ & $22^{\circ} 17.34^{\prime}$ & $119^{\circ} 52.50^{\prime}$ & 1178 & $229[3]$ & $\begin{array}{l}0-4 \mathrm{~cm} \text { : void; } 4-229 \mathrm{~cm} \text { : homogeneous dark gray muds } \\
\text { with pits and black spots; smelled of } \mathrm{H}_{2} \mathrm{~S} \text {. }\end{array}$ \\
\hline G21 & P2 & $22^{\circ} 15.29^{\prime}$ & $119^{\circ} 52.88^{\prime}$ & 1276 & $349[5]$ & $\begin{array}{l}0-10 \mathrm{~cm} \text { : void; } 75-78 \mathrm{~cm}, 165-176 \mathrm{~cm}, 226-229 \mathrm{~cm}, 312- \\
314 \mathrm{~cm} \text { : cracks; } 10-75 \mathrm{~cm} \text { : olive gray muds with hollows } \\
\text { and pits. } 75-150 \mathrm{~cm} \text { : dark gray muds mottled by black; } \\
\text { black laminations at intervals of } 93-100 \mathrm{~cm} \text { and } 107-109 \\
\mathrm{~cm} .150-349 \mathrm{~cm} \text { : homogeneous gray muds with black } \\
\text { spots at intervals of } 199-200 \mathrm{~cm} \text { and } 325-328 \mathrm{~cm} \text { (Fig. } 2 \mathrm{~h} \text { ). }\end{array}$ \\
\hline G23 & $\mathrm{P} 2$ & $22^{\circ} 21.17^{\prime}$ & $119^{\circ} 48.87^{\prime}$ & 1227 & $345[5]$ & $\begin{array}{l}0-5 \mathrm{~cm}, 150-151 \mathrm{~cm}, 225-227 \mathrm{~cm}, 300-301 \mathrm{~cm} \text { : void; } \\
90-91 \mathrm{~cm}, 107-108 \mathrm{~cm} \text { : cracks; The core is composed } \\
\text { of dark graymuds with increasing numbers of black } \\
\text { spots below the depth of } 110 \mathrm{~cm} \text {; smelled of } \mathrm{H}_{2} \mathrm{~S} \text {. }\end{array}$ \\
\hline \multicolumn{7}{|c|}{ Cruise OR1-718: } \\
\hline G4 & P2 & $22^{\circ} 08.86^{\prime}$ & $119^{\circ} 59.70^{\prime}$ & 1058 & $529[7]$ & $\begin{array}{l}\text { 0-34 cm, } 75-86 \mathrm{~cm}, 150-156 \mathrm{~cm}, 225-231 \mathrm{~cm}, 300-305 \\
\mathrm{~cm}, 375-378 \mathrm{~cm}, 450-455 \mathrm{~cm} \text { : void; } 156-162 \mathrm{~cm}, 230- \\
290 \mathrm{~cm}, 484-485 \mathrm{~cm}: \text { cracks; } 34-65 \mathrm{~cm}, 86-140 \mathrm{~cm} \text { : } \\
\text { with small pits; } 156-172 \mathrm{~cm}, 333-342 \mathrm{~cm}, 363-375 \mathrm{~cm} \text {, } \\
378-393 \mathrm{~cm} \text { : with black patches; The core is composed } \\
\text { of dark gray muds. }\end{array}$ \\
\hline $\mathrm{G} 24$ & $\mathrm{P} 2$ & $22^{\circ} 21.48^{\prime}$ & $119^{\circ} 48.51^{\prime}$ & 1098 & $310[3]$ & $\begin{array}{l}0-52 \mathrm{~cm}, 150-154 \mathrm{~cm}, 225-229 \mathrm{~cm} \text { : void; The core is } \\
\text { composed of dark gray muds with frequent occurrences } \\
\text { of black pits and laminations; smelled of } \mathrm{H}_{2} \mathrm{~S} \text {. }\end{array}$ \\
\hline N6 & $\mathrm{P} 2$ & $22^{\circ} 17.78^{\prime}$ & $119^{\circ} 53.21^{\prime}$ & 1164 & $436[6]$ & $\begin{array}{l}0-11 \mathrm{~cm}, 75-81 \mathrm{~cm}, 150-151 \mathrm{~cm}, 225-228 \mathrm{~cm}, 300-301 \\
\mathrm{~cm}, 375-377 \mathrm{~cm} \text { : void; } 11-36 \mathrm{~cm}, 151-193 \mathrm{~cm}, 403-404 \\
\mathrm{~cm} \text { : cracks; The core is composed of dark gray muds. }\end{array}$ \\
\hline N9 & $\mathrm{P} 2$ & $22^{\circ} 17.00^{\prime}$ & $120^{\circ} 00.81^{\prime}$ & 966 & $351[5]$ & $\begin{array}{l}\text { 0-9 cm, } 75-82 \mathrm{~cm}, 150-155 \mathrm{~cm}, 225-230 \mathrm{~cm}, 300-306 \\
\mathrm{~cm} \text { : void; } 25-35 \mathrm{~cm}, 104-107 \mathrm{~cm}, 192-193 \mathrm{~cm}, 205-212 \\
\mathrm{~cm}, 220-225 \mathrm{~cm}, 230-240 \mathrm{~cm}, 244-247 \mathrm{~cm}, 272-280 \mathrm{~cm} \text {, } \\
293-300 \mathrm{~cm}, 306-341 \mathrm{~cm} \text { : black patches and laminations; } \\
\text { The core is composed of dark gray muds (Fig. 2i). }\end{array}$ \\
\hline
\end{tabular}

Note:(1) At each station, two piston cores were retrieved. The first one (P1) is used for geological and geochemical studies, and the second one (P2) with a reference line for orientation is used for paleomagnetic and rock magnetic analyses.

(2) Ten cores longer than $2 \mathrm{~m}$ were cut into sections of $75-\mathrm{cm}$ length or less, and five cores shorter than $2 \mathrm{~m}$ keep the entire core as one section, except for core G15 P2 that is cut into two sections of 90-cm length. Sections obtained from each core are shown in the brackets.

(3) Detailed mineralogy and physical properties of sediments from the study area can be referred to Jiang et al. (2006).

(4) When cutting the cores into sections and putting them vertically for storage, water-containing sediments at the top of sections may precipitate, which forces water to migrate upward. In this situation, section at the top few centimeters is void when splitting it lengthwise. 
(a)

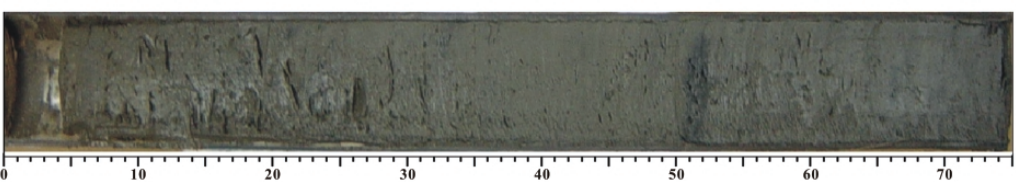

(b)

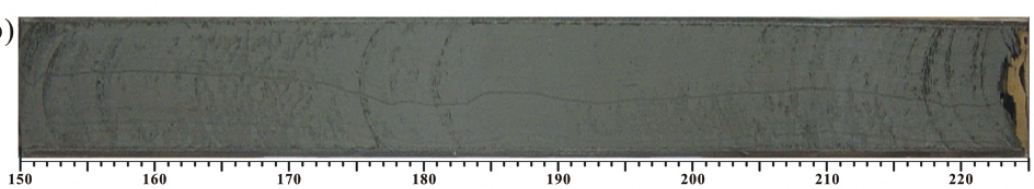

(c)

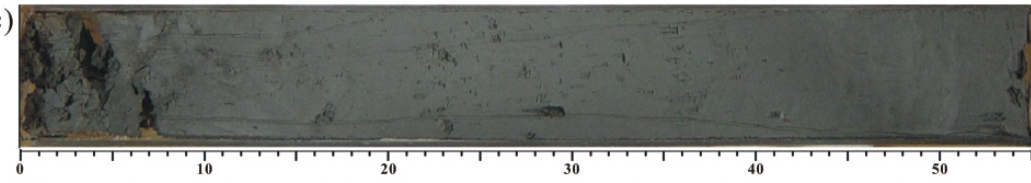

(d)

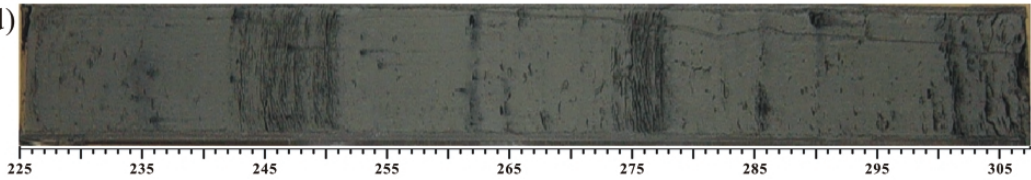

(e)

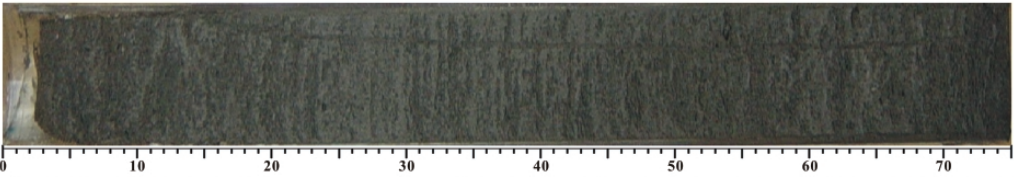

(f)

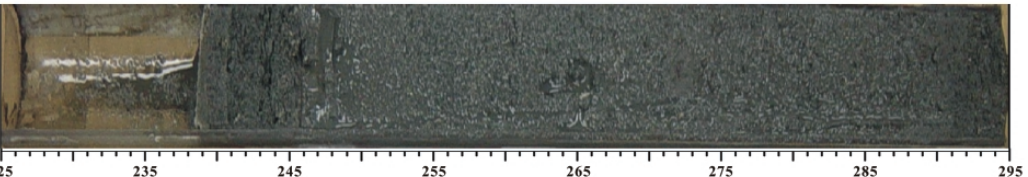

(g)

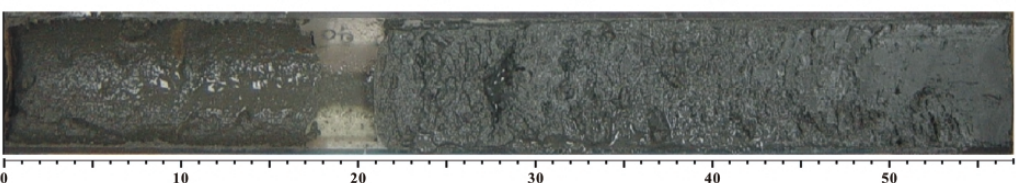

(h)

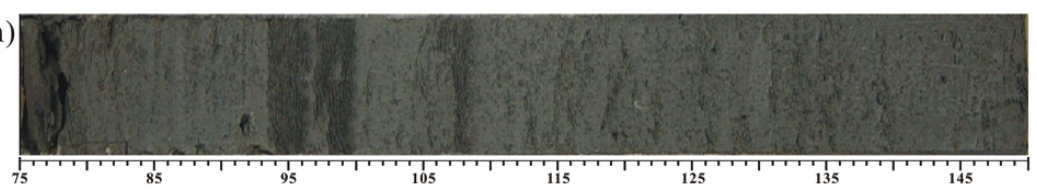

(i)

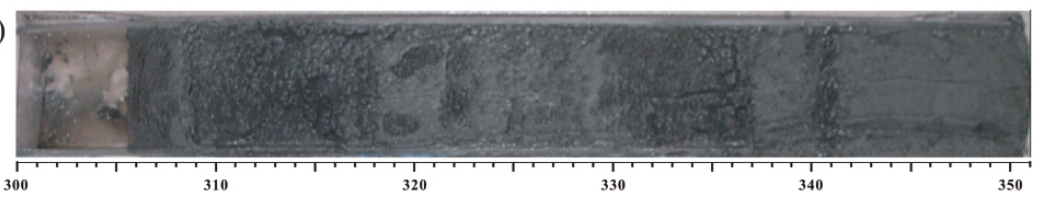

Fig. 2. Representative photos of core sections. (a) G1_P2: 0 - 75 cm, (b) G1_P2: 150 - $225 \mathrm{~cm}$, (c) G2_P2: 0 - $55 \mathrm{~cm}$, (d) G3_P2: 225 - $308 \mathrm{~cm}$, (e) G5_P2: 0 - $75 \mathrm{~cm}$, (f) G5_P2: 225 - $295 \mathrm{~cm}$, (g) G6_P2: 0 - $57 \mathrm{~cm}$, (h) G21_P2: $75-150 \mathrm{~cm}$, (i) N9_P2: $300-351 \mathrm{~cm}$. Core descriptions are presented in Table 1. 
and will not be shown. Magnetic minerals were extracted from bulk sediments using a rare earth magnet housed in a plastic sheath. A total of 134 magnetic extracts were obtained from different core depths of the fifteen cores. X-ray diffraction (XRD) analysis on the magnetic extracts was made using a Rikagu Miniflex tabletop unit ( $\mathrm{Cu}-\mathrm{K} \alpha$ radiation); scans were run from $4^{\circ}$ to $80^{\circ}$ of $2 \theta$. Results are presented after subtraction of the background trend.

\section{RESULTS}

\subsection{Magnetic Susceptibility Profiles}

Figure 3 presents the down core profiles of magnetic susceptibility of u-channels from the fifteen cores. The data reveal several features: (1) Cores of G1, G3, G4, G5, G17, G19, G21, G23, N6, and N9 have values ranging from 8 to $15 \times 10^{-6}$ SI for the most part of their lengths, while cores of G2, G6, G10, and G24 usually have values higher than $15 \times 10^{-6} \mathrm{SI}$; (2) High peak values of magnetic susceptibility $\left(>20.0 \times 10^{-6} \mathrm{SI}\right.$ ) occur sporadically at certain depths in G2, G15, G17, G19, G23, G24, and N6; (3) Magnetic susceptibility increases significantly with depth in G6. On the other hand, magnetic susceptibility decreases to the level of $4-8 \times 10^{-6} \mathrm{SI}$ in the lower part of G4 and G5; (4) G23 has relatively larger fluctuations in the upper part (0 $150 \mathrm{~cm}$ ), compared to its lower part; (5) The entire core of G15 has monotonous, lower magnetic susceptibility values $\left(<8 \times 10^{-6} \mathrm{SI}\right)$, except for two peaks in the interval 50 to $70 \mathrm{~cm}$. Because values of magnetic susceptibility are mainly controlled by the kind and concentration of magnetic minerals, the above magnetic susceptibility profiles imply that the sedimentary sequences contain different kinds of magnetic minerals and/or have various magnetic concentrations both within and among the cores.

\subsection{Magnetic Mineral Assemblages}

XRD analysis on magnetic extracts from different core depths indicates that magnetite and greigite are the dominant magnetic minerals in the sediments (Figs. 4a, b), although their relative concentrations are variable. Non-magnetic pyrite is also identified. Pyrite is generally associated with greigite, but it may co-exist with magnetite or may occur solely when the concentration of magnetic minerals is below the detection limit of XRD (Figs. 4c - e). The magnetic mineral assemblages identified by XRD analysis for the 134 magnetic extracts from different core depths of the fifteen cores are summarized in Table 2. Based on the results in Table 2, the following remarks can be made: (1) Except for G2 and G6, magnetite is almost omnipresent in all of the cores. Among these cores, magnetite may occur from the core top to certain depths (e.g., G1, G5, G10, G15, G17, and G19) or down to the core bottom (e.g., G3, G4, G21, G23, G24, N6, and N9); (2) Greigite and/or pyrite may occur in cores either at very shallow depths (e.g., G2, G6, G10, G19, G23, G24) or at greater depths (G1, G4, G5, G17, N6), where magnetite is co-existent or completely absent; (3) In G15, only magnetite was found in sediments above a core depth of $20 \mathrm{~cm}$. The concentration of magnetic extracts below this depth is too low to be detected by XRD. The limited quantity of magnetic extracts indicates that no magnetic minerals exist below this depth. It is also noted that only pyrite was detected below a core depth of $205 \mathrm{~cm}$ in G5. 

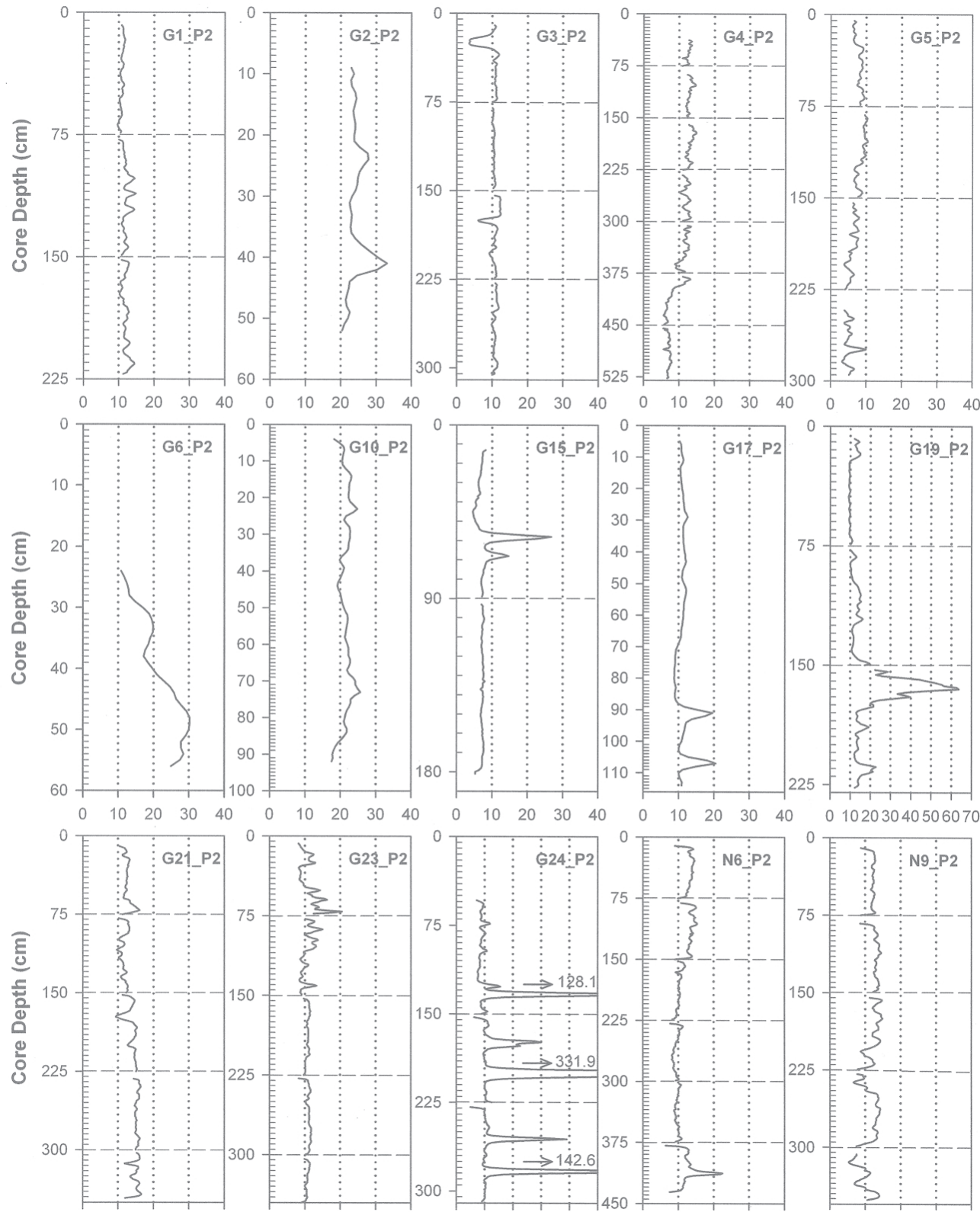

$\begin{array}{llllllllllllllllllllllllll}0 & 10 & 20 & 30 & 40 & 0 & 10 & 20 & 30 & 40 & 0 & 20 & 40 & 60 & 80 & 100 & 0 & 10 & 20 & 30 & 40 & 0 & 10 & 20 & 30 & 40\end{array}$ Magnetic Susceptibility Magnetic Susceptibility Magnetic Susceptibility Magnetic Susceptibility Magnetic Susceptibility (E-6, SI)

$(\mathrm{E}-6, \mathrm{SI})$

(E-6, SI)

$(\mathrm{E}-6, \mathrm{SI})$

(E-6, SI)

Fig. 3. Down core profiles of magnetic susceptibility of the u-channel samples from the fifteen piston cores. Horizontal dashed lines indicate ends of core sections. Measurement data at the ends of u-channels (ca. $4 \mathrm{~cm}$ ) were discarded due to free space effects. 

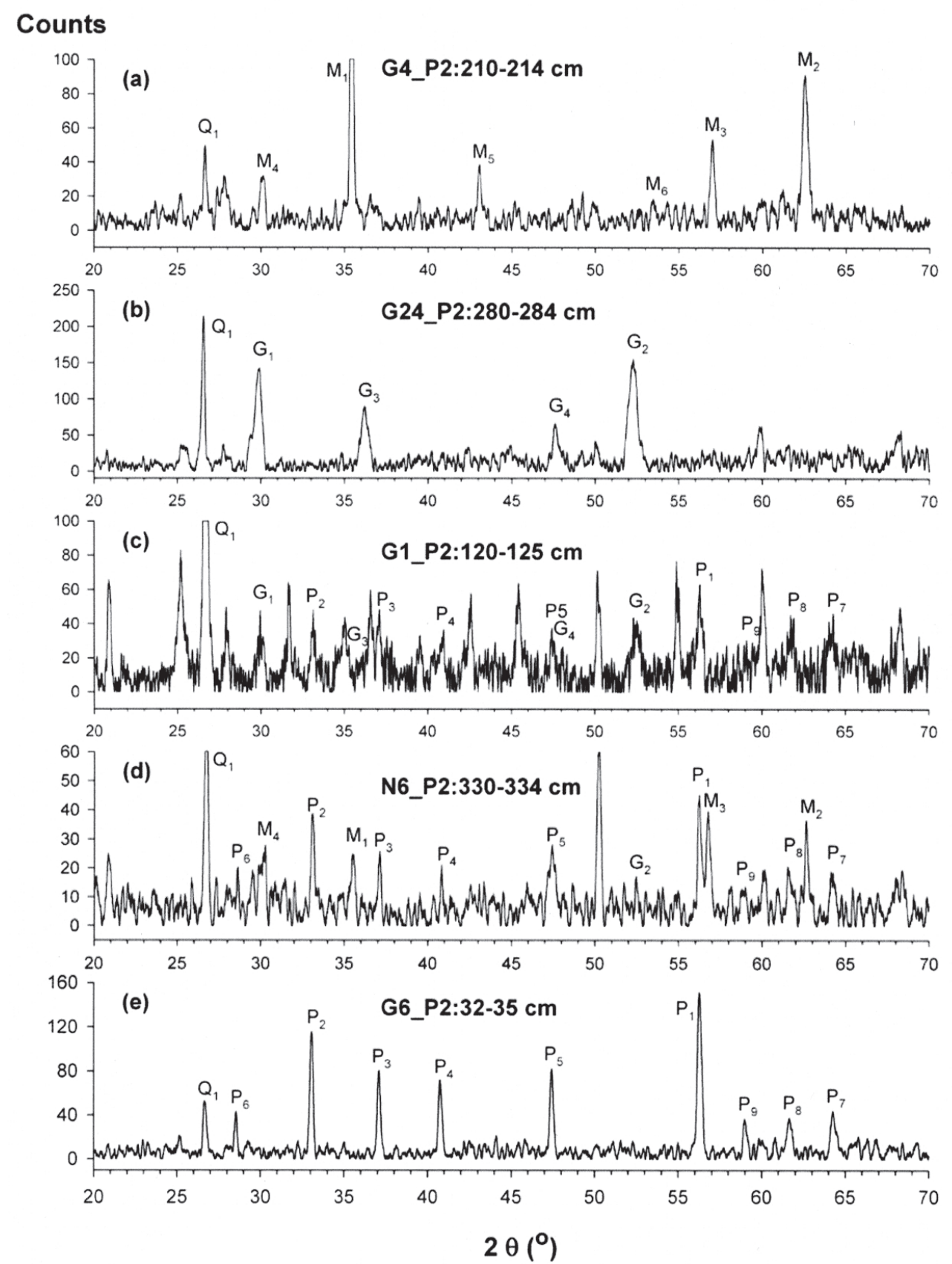

Fig. 4. Representative X-ray diffraction data for magnetic extracts from the intervals of the studied piston cores. The main peaks for magnetite $\left(M_{1}-M_{6}\right)$, greigite $\left(G_{1}-G_{4}\right)$, pyrite $\left(P_{1}-P_{9}\right)$ and Quartz $\left(Q_{1}\right)$ are shown. Peak intensities that are over-scale have been cut. 
Table 2. Magnetic mineral assemblages identified by XRD analysis for magnetic extracts from the fifteen piston cores of the cruises of OR1-697 and OR1-718.

\begin{tabular}{|c|c|c|c|c|c|c|c|c|c|c|c|c|}
\hline \multirow{2}{*}{$\begin{array}{l}\text { Cores } \\
\text { G1 }\end{array}$} & \multirow{2}{*}{$\begin{array}{c}\begin{array}{c}\text { Interval } \\
(\mathrm{cm})\end{array} \\
5-10\end{array}$} & \multicolumn{2}{|c|}{$\begin{array}{l}\text { Magnetic } \\
\text { Minerals }\end{array}$} & \multirow{2}{*}{$\begin{array}{l}\text { Cores } \\
\text { G6 }\end{array}$} & \multirow{2}{*}{$\begin{array}{c}\begin{array}{c}\text { Interval } \\
(\mathrm{cm})\end{array} \\
22-25\end{array}$} & \multicolumn{2}{|c|}{$\begin{array}{l}\text { Magnetic } \\
\text { Minerals }\end{array}$} & \multirow{2}{*}{$\begin{array}{l}\text { Cores } \\
\text { G23 }\end{array}$} & \multirow{2}{*}{$\begin{array}{c}\begin{array}{c}\text { Interval } \\
(\mathrm{cm})\end{array} \\
14-15\end{array}$} & \multicolumn{3}{|c|}{$\begin{array}{l}\text { Magnetic } \\
\text { Minerals }\end{array}$} \\
\hline & & M & & & & G & $\mathrm{P}$ & & & M & & $\mathrm{P}$ \\
\hline & $30-35$ & M & & & 27-30 & & $\mathrm{P}$ & & $24-25$ & M & & $\mathrm{P}$ \\
\hline & $50-55$ & M & & & $32-35$ & & $\mathrm{P}$ & & $34-35$ & M & & \\
\hline & $80-85$ & & $\mathrm{P}$ & & $37-40$ & G & $\mathrm{P}$ & & $39-40$ & M & & \\
\hline & $120-125$ & G & $\mathrm{P}$ & & $42-45$ & G & $\mathrm{P}$ & & $44-45$ & & & $\mathrm{P}$ \\
\hline & $160-165$ & G & $\mathrm{P}$ & & $47-50$ & G & $\mathrm{P}$ & & $49-50$ & & G & $\mathrm{P}$ \\
\hline & $200-205$ & G & $\mathrm{P}$ & & $52-55$ & G & $\mathrm{P}$ & & $69-70$ & & & $\mathrm{P}$ \\
\hline & & & $a_{2}$ & & & & & & $89-90$ & & G & $\mathrm{P}$ \\
\hline \multirow[t]{3}{*}{ G2 } & $7-10$ & G & $\mathrm{P}$ & G10 & $2-5$ & M & $\mathrm{P}$ & & $114-115$ & & G & $\mathrm{P}$ \\
\hline & $22-25$ & G & $\mathrm{P}$ & & $42-45$ & G & $\mathrm{P}$ & & $139-140$ & & G & \\
\hline & $37-40$ & G & $\mathrm{P}$ & & $82-85$ & G & $\mathrm{P}$ & & $149-150$ & M & & \\
\hline \multirow[t]{9}{*}{ G3 } & $7-13$ & M & & G15 & $9-10$ & M & & & $229-230$ & M & & \\
\hline & $35-40$ & M & & & $19-20$ & M & & & $259-260$ & M & & \\
\hline & $55-60$ & M & & & $29-30$ & NA & & & $269-270$ & & G & $\mathrm{P}$ \\
\hline & $95-100$ & M & & & $39-40$ & NA & & & $309-310$ & M & & \\
\hline & $135-140$ & M & & & $49-50$ & NA & & & & & & \\
\hline & $165-170$ & M & & & $59-60$ & NA & & G24 & $51-55$ & M & $\mathrm{G}$ & \\
\hline & $200-205$ & M & & & $69-70$ & NA & & & $80-84$ & M & G & \\
\hline & $245-250$ & M & & & $79-80$ & NA & & & $110-114$ & M & G & \\
\hline & $275-280$ & M & & & $89-90$ & NA & & & $130-134$ & M & G & \\
\hline & & & & & $99-100$ & NA & & & $170-174$ & M & G & \\
\hline \multirow[t]{15}{*}{ G4 } & $31-37$ & M & & & $109-110$ & NA & & & $200-204$ & M & G & \\
\hline & $70-74$ & M & & & $119-120$ & NA & & & $240-244$ & M & & \\
\hline & $90-94$ & M & & & & & $\ldots$ & & $255-259$ & M & G & \\
\hline & $130-134$ & M & & G17 & $4-5,9-10,14-15$ & M & & & $280-284$ & & G & \\
\hline & $170-174$ & M & & & $39-40,44-45,49-50$ & & $\mathrm{P}$ & & $300-304$ & M & G & \\
\hline & $210-214$ & M & & & 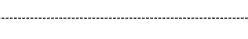 & & - & $\cdots \cdots \cdots$ & & & & \\
\hline & $250-254$ & M & & G19 & $12-15$ & M & $P$ & N6 & $10-14$ & M & & \\
\hline & $290-294$ & M & & & $32-35$ & & $P$ & & $50-54$ & M & & \\
\hline & $330-334$ & M & & & $72-75$ & $M \quad G$ & & & $90-94$ & M & & \\
\hline & $370-374$ & M & $\mathrm{P}$ & & $102-105$ & & $\mathrm{P}$ & & $130-134$ & M & & \\
\hline & $410-418$ & M & & & $117-120$ & G & $\mathrm{P}$ & & $170-174$ & M & & \\
\hline & $418-430$ & $M G$ & $P$ & & $162-165$ & & $P$ & & $210-214$ & M & & \\
\hline & $470-486$ & M & $\mathrm{P}$ & & $212-215$ & G & $\mathrm{P}$ & & $250-254$ & M & & \\
\hline & $510-526$ & M & $\mathrm{P}$ & & & 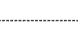 & & & $290-294$ & M & & \\
\hline & & & 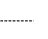 & G21 & $9-10,14-15,19-20$ & M & & & $330-334$ & M & G & $\mathrm{P}$ \\
\hline \multirow[t]{12}{*}{ G5 } & $2-5$ & M & & & $29-30,34-35,39-40$ & M & & & $370-374$ & M & & $\mathrm{P}$ \\
\hline & $42-45$ & M & & & $54-55,59-60,64-65$ & M & & & $410-414$ & M & G & \\
\hline & $82-85$ & M & & & 89-90, 94-95, 99-100 & M & & & $-\sigma_{2}=\sigma_{2}$ & $a_{3}$ & & \\
\hline & $102-105$ & M & & & $4-125,129-130,134-135$ & M & & N9 & $9-14$ & M & & \\
\hline & $122-125$ & $M G$ & & & $4-155,159-160,164-165$ & M & & & $50-54$ & M & & \\
\hline & $142-145$ & & $P$ & & $9-190,194-195,199-200$ & M & & & $90-94$ & M & & \\
\hline & $162-165$ & $M G$ & & & $4-235,239-240,244-245$ & M & & & $130-134$ & M & & \\
\hline & $202-205$ & $\mathrm{M} \mathrm{G}$ & $\mathrm{P}$ & & $4-265,269-270,274-275$ & M & & & $170-174$ & M & & \\
\hline & $242-245$ & NA & & & $4-305,309-310,314-315$ & M & & & $210-214$ & M & & \\
\hline & $272-275$ & & $P$ & & $4-335,339-340,344-345$ & M & & & $250-254$ & M & & \\
\hline & $283-285$ & & $\mathrm{P}$ & & r & 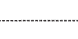 & $\cdots \cdots$ & & $290-294$ & M & & \\
\hline & $288-290$ & & $\mathrm{P}$ & G23 & $9-10$ & M & $\mathrm{P}$ & & $330-334$ & M & & \\
\hline
\end{tabular}

Note: (1) Two magnetic minerals, magnetite (M) and greigite (G), were identified by XRD analysis in the study samples. Although pyrite $(\mathrm{P})$ is non-magnetic, it is generally associated with greigite and magnetite and can be therefore detected. It should be aware that samples showing pyrite as a single phase should contain very small amounts of greigite and/or magnetite, but they are below the detect limit of XRD. For the samples showing NA (not available), it means that their magnetic extracts are insufficient for XRD analysis. 


\section{DISCUSSION}

\subsection{Different Diagenetic Effects on Sediments}

The complicated magnetic mineral occurrences of magnetite, greigite and pyrite in core samples (Table 2) explain why the magnetic susceptibility profiles within each core and among all cores are so variable (Fig. 3), and this indicates that their sediments have encountered different diagenetic effects ranging from oxic to anoxic conditions. As magnetite is so widely present in the sediments, it is reasonable to propose that magnetite is mainly from detritus. The presence of only magnetite in the entire cores of G3, G21 and N9, and in the upper sequences of several cores (e.g., G1, G4, G5, G15, G17, and N6) suggests that these host sediments are under oxic (or sub-oxic) diagenetic conditions. Figure 3 shows their magnetic susceptibilities to have moderate values with small variations, ranging from 8 to $15.0 \times 10^{-6} \mathrm{SI}$. These variations should simply reflect slight changes in magnetite concentration and can be therefore regarded as the magnetic susceptibility backgrounds of sediments initially deposited in the study area.

On the other hand, the presence of greigite and/or pyrite (Table 2) indicates that anoxic conditions prevailed in the study area for their formation to have occurred during the early diagenetic process. In several cases, like in the entire cores of G2 and G6, and in the lower parts of several cores (e.g., G1, G5, G10, G15, G17, G19), the extent of the anoxic diagenetic process caused the complete dissolution of magnetite. In this situation, greigite contributes predominantly to the magnetic susceptibilities of sediments; the values of which are closely related to its concentrations. As the volume specific magnetic susceptibility of greigite is $5-7$ times lower than that of magnetite (see Maher et al. 1999) and the local magnetic susceptibility backgrounds from magnetite are between 8 and $15.0 \times 10^{-6} \mathrm{SI}$, core sequences having magnetic susceptibilities higher than the background values (e.g., G2, G6, G10 and G24), particularly for those high peaks at certain depths (see Fig. 3), should be due to the enrichment of greigite produced during the anoxic diagenetic process.

Another interesting case revealed from Table 2 is that no magnetic minerals exist for almost the entire sequence of G15, which corresponds to the lowest magnetic susceptibilities $\left(<8 \times 10^{-6} \mathrm{SI}\right)$ due to the non-magnetic sediment matrix. A similar case is also found in the lower part of G5, where pyrite replaces magnetite and greigite as the dominant authigenic mineral, indicating that complete reduction of iron minerals to pyrite may have occurred.

\subsection{Implications of Carbon-Sulfur-Iron Signatures for the Occurrences of Magnetic Minerals}

During sediment burial in marine environments, the supplies of organic matter, sulfate, and reactive iron are the three main factors that control the formation of iron sulfide minerals (Goldhaber and Kaplan 1974; Berner 1984; Morse et al. 1987; Wilkin and Barnes 1997). As a result of dilution by extremely high input of terrestrial sediments, the contents of total organic carbon (TOC) in near-surface sediments off southwestern Taiwan are very low, mostly ranging from 0.35 to $0.70 \mathrm{wt} \%$ (Kao et al. 2004a; Hung and Hsu 2004). The TOC analyses on sediments also reveal that a plume-like patch of relatively high TOC contents extends southward from the Kaoping River mouth (Fig. 1b), suggesting that the Kaoping River carries the 
main supply of organic-rich sediments and implying that terrestrial organics may have significantly contributed to sedimentary organic matter in the study area. Analyses of total sulfur (TS) and reactive iron $\left(\mathrm{Fe}_{\mathrm{A}}\right)$ in sediments of the area also reveal unusually low sulfur contents (mostly below $0.07 \mathrm{wt} \%$ ) but rich reactive iron (1.2 - $2.0 \mathrm{wt} \%$ ) (Kao et al. 2004a). Consequently, the degree of sulfidation, a useful index of the diagenetic condition for the formation of iron sulfide minerals (Boesen and Postma 1988; Leventhal and Tayor 1990), is very low (mostly below 6\%), indicating that the initial geochemical conditions in the near-surface sediments were not favorable for the formation of iron sulfide minerals (Kao et al. 2004a).

Inland of southwestern Taiwan, authigenic greigite has been widely found in the PlioPleistocene marine sedimentary sequences (Horng et al. 1992, 1998; Torii et al. 1996). It commonly occurs in fine-grained mudstones in contrast to magnetite that survives and predominates in the sandy strata. In these ancient sequences, Kao et al. (2004b) reported that magnetite-dominated sediments have low TOC $(0.32 \pm 0.03 \mathrm{wt} \%)$, low TS $(0.07 \pm 0.01 \mathrm{wt} \%)$, and high $\mathrm{Fe}_{\mathrm{A}}(1.82 \pm 0.09 \mathrm{wt} \%)$, whereas greigite-dominated sediments have values of TOC $(0.46 \pm 0.04 \mathrm{wt} \%)$, TS $(0.13 \pm 0.03 \mathrm{wt} \%)$, and $\mathrm{Fe}_{\mathrm{A}}(2.15 \pm 0.18 \mathrm{wt} \%)$, higher than those in magnetite-dominated sediments. Comparing these results with the data of modern sediments, we propose that the near-surface sediments off southwestern Taiwan reported by Kao et al. (2004a) should have detrital magnetite as the dominant magnetic mineral because their initial geochemical signatures are consistent with those observed in the ancient magnetite-dominated sediments. However, the TS contents in the ancient greigite-dominated sediments are almost two-times higher than the TS contents in the magnetite-dominated sediments. In fact, much higher TS contents $(0.31-0.64 \mathrm{wt} \%)$ have been measured in our study sediments with greigite as the dominant magnetic mineral (C. S. Horng, unpublished data). The higher TS both in modern and ancient sediments indicate that anoxic diagenetic process has been widely occurring in the area off southwestern Taiwan since the Plio-Pleistocene, which has led to the formation or the enrichment of greigite.

\subsection{Possible Influence of Methane Flux on Magnetic Mineral Compositions}

Kao et al. (2004a) have pointed out that the contents of sedimentary organic matter in the marine sediments offshore of southwestern Taiwan are very low. In addition, based on the studies of river-borne organic matter in northeastern Taiwan (Kao and Liu 1996, 1997), they proposed that there probably was a high fraction of refractory carbon in the sedimentary organics and thus the real fraction of organic matter that is available for sulfate-reducing bacteria should be considerably limited. Accordingly, it seems unlikely that the widespread and longstanding reducing environments that resulted in the formation/enrichment of greigite in southwestern Taiwan can be simply attributed to the very limited amount of organic matter from deposition.

Alternatively and possibly, the main source of additional organic matter to form the widespread and longstanding reducing environments off southwestern Taiwan is gaseous methane related with gas hydrates in deeper layers. As high-concentration methane has been commonly found in the near-surface sediments of the study area (Chuang et al. 2006; Oung et al. 2006), this provides a clue to the source of additional organic carbon. This methane gas prob- 
ably rises along conduits formed by the prevailing fold-and-thrust structures in the accretionary wedge. Novosel et al. (2005) proposed two main types of upward gas migration within the accretionary wedge: (1) a distributed migration through the sedimentary matrix, occurring over a large area; (2) a focused migration, occurring along cracks and faults within the sedimentary matrix. The first one can be regarded as gas diffusion because gas flux at a given location is quite small, although in this case the absolute amount of gas flux could be large since it is widely distributed. The second alternative is gas venting, which can be detected more readily than gas diffusion by geophysical and geochemical methods. For instance, sediments that experience gas venting generally reveal prominent low magnetic susceptibilities because of the complete reduction of high-susceptibility magnetic minerals, including magnetite and greigite, to pyrite through the reaction of increased methane flux and near-surface sulfate. In accordance with these ideas proposed by Novosel et al. (2005), we infer that gas diffusion is a more likely candidate mechanism for the formation/enrichment of greigite because a small methane flux forms a mild reducing environment.

If the above inference is correct, our data that reveal complicated magnetic mineral assemblages and variable magnetic susceptibility profiles can be interpreted in terms of methane flux causing a variety of diagenetic effects on sediments in the accretionary wedge offshore of southwestern Taiwan. For sediments where methane gas is not accessible or its flux is too small to form authigenic iron sulfides, detrital magnetite will survive and it is the only magnetic mineral that can be detected in the sediments. This case can be illustrated by the entire cores of G3, G21, and N9, and in the upper sequences of several cores, such as G1, G4, G5, G15, G17, and N6 (Table 2). Once sediments were furnished by methane through gas diffusion with variable flux intensities, then various mixtures of greigite and pyrite formed, accompanying either the survival or complete dissolution of magnetite. This case can be commonly observed in the lower or entire sequences of most cores studied, except for G3, G21, and N9. However, it seems that methane flux intensity should have been high in the lower part of G5 and G15, because it resulted in a complete reduction of magnetite and greigite to pyrite and caused a decrease in magnetic susceptibilities below background levels (Fig. 3). Such a case may represent gas-venting phenomena.

As revealed in G1, G4, G5, G10, G15, G17, G19, and N6 (Table 2), the magnetic mineral occurrences, with authigenic greigite and pyrite usually forming in the lower sediment sequences and detrital magnetite generally surviving in the upper sequences, apparently support our inference that reducing environments were furnished by the upward methane gas. More evidence for supporting this mechanism is the downward increase in magnetic susceptibilities in G6 (Fig. 3), reflecting an enrichment of greigite at greater depths. It is noted from Table 2 that cores G1, G2, G6, G10, G19, G23, and G24, located at the topographic highs (Figs. 1c, d), have shallower depths of greigite-bearing sediments, compared with the depths in G3, G4, G21, N6, and N9 that are close to or in the topographic lows. This evidence reveals that conduits, such as growing thrust faults, should be present beneath the topographic highs for methane upward migration.

Although upward movement is the main mode of methane migration, advection of methane gas cannot be excluded. We attribute the cause of the greigite-enriched spikes, observed in the certain intervals of the magnetic susceptibility profiles, to this kind of migration. 
Furthermore, the relatively large susceptibility fluctuations in the upper sequence $(0-150 \mathrm{~cm})$ of G23 can be also interpreted by greigite/pyrite formation through advection of methane gas. The enrichment of greigite and pyrite due to gas diffusion and venting implies that there ought to have been an extra seawater supply of sulfate downward through cracks and faults to react with additional methane gas.

\section{CONCLUSIONS}

Rock-magnetic analyses, mainly magnetic susceptibility measurement and magnetic mineral identification, on piston-cored sediments from the accretionary wedge offshore of southwestern Taiwan reveal that down core sediments have complicated magnetic mineral occurrences, with variable concentrations of detrital magnetite and authigenic greigite/pyrite. This indicates that sediments have suffered different diagenetic effects under oxic to anoxic conditions. In the oxic (or sub-oxic) environments, detrital magnetite survives, whereas authigenic greigite/pyrite forms in the anoxic environments. Because the contents of organic matter in sediments are too low to support anoxic conditions, we propose that gaseous methane rising from deeper sedimentary layers is the main cause for the formation of reducing environments in sediments. The upward migration of methane can be either through diffusion or venting, which controls gas flux intensities and ultimately affects the formation of iron sulfides as greigite and/or pyrite. Because greigite, methane-related mud volcanoes and coldseep carbonates have been found in the Plio-Pleistocene marine-deposited sedimentary sequences of southwestern Taiwan, the activities of methane gas diffusion and venting can be therefore traced back to the Plio-Pleistocene age.

Acknowledgements This study was conducted as a gas-hydrate project funded by the Central Geological Survey, the Ministry of Economic Affairs. We thank Dr. Yun-Shuen Wang, Mr. San-Hsiung Chung, Professors Ju-Chin Chen and Char-Shine Liu for arranging and coordinating the project. Special thanks to Dr. Saulwood Lin, the technicians and the crew of RV Ocean Research-I for recovering the piston cores during the cruises. We are grateful to Chyi-Kun Yao and Yi-Chun Chen for laboratory assistances. Helpful comments and suggestions from Masayuki Torii and Eugene Huang to improve the manuscript are greatly appreciated.

\section{REFERENCES}

Barnes R. O., and E. D. Goldberg, 1976: Methane production and consumption in anoxic marine sediments. Geology, 4, 297-300.

Berner, R. A., 1984: Sedimentary pyrite formation. Am. J. Sci., 268, 1-23.

Boesen, C., and D. Postma, 1988: Pyrite formation in anoxic environments of the Baltic. Am. J. Sci., 288, 575-603.

Borowski, W. S., C. K. Paull, and W. Ussler III, 1996: Marine pore-water sulfate profiles indicate in situ methane flux from underlying gas hydrate. Geology, 24, 655-658. 
Canfield, D. E., and R. A. Berner, 1987: Dissolution and pyritization of magnetite in anoxic marine sediments. Geochim. Cosmochim. Acta, 51, 645-659.

Chen, C. T. A., and H. C. Tseng, 2006: Abnormally high $\mathrm{CH}_{4}$ concentrations in seawater at mid-depths on the continental slopes of the northern South China Sea. Terr. Atmos. Ocean. Sci., 17, 951-959.

Chi, W. C., D. L. Reed, C. S. Liu, and N. Lundberg, 1998: Distribution of the bottom-simulating reflector in the offshore Taiwan collision zone. Terr. Atmos. Ocean. Sci., 9, 779794.

Chuang, P. C., T. F. Yang, S. Lin, H. F. Lee, T. F. Lan, W. L. Hong, C. S. Liu, J. C. Chen, and Y. Wang, 2006: Extremely high methane concentration in bottom water and cored sediments from offshore southwestern Taiwan. Terr. Atmos. Ocean. Sci., 17, 903-920.

Garming, J. F. L., U. Bleil, and N. Riedinger, 2005: Alteration of magnetic mineralogy at the sulfate-methane transition: analysis of sediments from the Argentine continental slope. Phys. Earth Planet. In., 151, 290-308.

Goldhaber, M. B., and I. R. Kaplan, 1974: The sulfur cycle. In: Goldberg, E. D. (Ed.), The Sea, Vol. 5., Wiley Press, New York, 569-656.

Gong, S. Y., T. Y. Lee, J. C. Wu, S. W. Wang, and K. M. Yang, 1996: Possible links between the development of Plio-Pleistocene coral reef limestones and thrust migration in southwestern Taiwan. J. Geol. Soc. China, 39, 151-166.

Horng, C. S., J. C. Chen, and T. Q. Lee, 1992: Variations in magnetic minerals from two PlioPleistocene marine-deposited sections, southwestern Taiwan. J. Geol. Soc. China, 35, 323-335.

Horng, C. S., M. Torii, K. S. Shea, and S. J. Kao, 1998: Inconsistent magnetic polarities between greigite- and pyrrhotite/magnetite-bearing marine sediments from the Tsailiaochi section, southwestern Taiwan. Earth Planet. Sci. Lett., 164, 467-481.

Hung J. J., and C. L. Hsu, 2004: Present state and historical changes of trace metal pollution in Kaoping coastal sediments, southwestern Taiwan. Mar. Pollut. Bull., 49, 986-998.

Kao, S. J., and K. K. Liu, 1996: Particulate organic carbon export from a subtropical mountainous river (Lanyang-Hsi) in Taiwan. Limnol. Oceanogr., 41, 1749-1757.

Kao, S. J., and K. K. Liu, 1997: Fluxes of dissolved and nonfossil particulate organic carbon from an Oceania small river (Lanyang-Hsi) in Taiwan. Biogeochemistry, 39, 255-269.

Kao, S. J., S. C. Hsu, C. S. Horng, and K. K. Liu, 2004a: Carbon-sulfur-iron relationships in the rapidly accumulating marine sediments off southwestern Taiwan. In: Hill et al. (Eds.), Geochemical Investigations in Earth and Space Science, Elsevier, 441-457.

Kao, S. J., C. S. Horng, A. P. Roberts, and K. K. Liu, 2004b: Carbon-sulfur-iron relationships in sedimentary rocks from southwestern Taiwan: influence of geochemical environment on greigite and pyrrhotite formation. Chem. Geol., 203, 153-168.

Kirschvink, J. L., and S. B. R. Chang, 1984: Ultra-fine grained magnetite in deep sea sediments: possible bacterial magnetofossil. Geology, 12, 559-562.

Leslie, B. W., S. P. Lund, and D. E. Hammond, 1990: Rock magnetic evidence for the dissolution and authigenic growth of magnetic minerals within anoxic marine sediments of the California continental borderland. J. Geophys. Res., 95, 4437-4452.

Leventhal, J. S., and C. Tayor, 1990: Comparison of methods to determine the degree of pyritisation. Geochim. Cosmochim. Acta, 54, 2621-2625. 
Liu, C. S., I. L. Huang, and L. S. Teng, 1997: Structural features off southwestern Taiwan. Mar. Geol., 137, 305-319.

Liu, C. S., P. Schnürle, Y. Wang, S. H. Chung, S. C. Chen, and T. H. Hsiuan, 2006: Distribution and characters of gas hydrate offshore of southwestern Taiwan. Terr. Atmos. Ocean. Sci., 17, 615-644.

Liu, X., and P. B. Flemings, 2006: Passing gas through the hydrate stability zone at southern Hydrate Ridge, offshore Oregon. Earth Planet. Sci. Lett., 241, 211-226.

Løvlie, R., W. Lowrie, and M. Jacobs, 1971: Magnetic properties and mineralogy of four deep-sea cores. Earth Planet. Sci. Lett., 15, 157-168.

Maher, B. A., R. Thompson, and M. W. Hounslow, 1999: Chapter I- Introduction. In: Maher, B. A., and R. Thompson (Eds.), Quaternary Climates, Environments and Magnetism, Camb. Univ. Press, Cambridge, 1-48.

Morse, J. W., F. J. Millero, J. C. Cornwell, and D. Rickard, 1987: The chemistry of the hydrogen sulfide and iron sulfide system in natural waters. Earth-Sci. Rev., 24, 1-42.

Novosel, I., G. D. Spence, and R. D. Hyndman, 2005: Reduced magnetization produced by increased methane flux at a gas hydrate vent. Mar. Geol., 216, 265-274.

Opdyke, N. D., 1972: Paleomagnetism of deep-sea cores. Rev. Geophys. Space Phys., 10, 213-249.

Oung, J. N., C. Y. Lee, C. S. Lee, and C. L. Kuo, 2006: Geochemical study on hydrocarbon gases in seafloor sediments, southwestern offshore Taiwan - implications in the potential occurrence of gas hydrates. Terr. Atmos. Ocean. Sci., 17, 921-931.

Reed, D. L., N. Lundberg, C. S. Liu, and B. Y. Kuo, 1992: Structural relations along the margins of the offshore Taiwan accretionary wedge: implications for accretion and crustal kinematics. Acta Geol. Taiwanica, 30, 105-122.

Schnürle, P., T. H. Hsiuan, and C. S. Liu, 1999: Constrains on free gas and gas hydrate bearing sediments from multi-channel seismic data, offshore south western Taiwan. Petrol. Geol. Taiwan, 33, 21-42.

Schoonen, M. A. A., and H. L. Barnes, 1991: Reactions forming pyrite and macasite from solution: II. via FeS precursors below 100 degree C. Geochim. Cosmochim. Acta, 55, 1505-1514.

Shih, T. T., 1967: A survey of the active mud volcanoes in Taiwan and a study of their types and the character of the mud. Petrol. Geol. Taiwan, 5, 259-311.

Sloan, E. D., 1998: Clathrate hydrates of natural gases, Marcel Dekker Press, New York, 705 pp.

Sun, S. C., and C. S. Liu, 1993: Mud diapirs and submarine channel deposits in offshore Kaohsiung-Hengchun, southwest Taiwan. Petrol. Geol. Taiwan, 28, 1-14.

Torii, M., K. Fukuma, C. S. Horng, and T. Q. Lee, 1996: Magnetic discrimination of pyrrhotiteand greigite-bearing sediment samples, Geophys. Res. Lett., 23, 1813-1816.

Wang, S. W., S. Y. Gong, H. S. Mii, and C. F. Dai, 2006: Cold-seep carbonate hardgrounds as the initial substrata of coral reef development in a siliciclastic paleoenvironment of southwestern Taiwan. Terr. Atmos. Ocean. Sci., 17, 405-427.

Week, R., C. Laj, L. Endignoux, M. Fuller, A. Roberts, R. Manganne, E. Blanchard, and W. Goree, 1993: Improvements in long-core measurement techniques: applications in palaeomagnetism and palaeoceanography. Geophys. J. Int., 114, 651-662. 
Wilkin, R. T., and H. L. Barnes, 1996: Pyrite formation by reactions of iron monosulfides with dissolved inorganic and organic sulfur species. Geochim. Cosmochim. Acta, 60, 4167-4179.

Wilkin, R. T., and H. L. Barnes, 1997: Pyrite formation in an anoxic estuarine basin. Am.J. Sci., 297, 620-650.

Yang, T. F., G. H. Yeh, C. C. Fu, C. C. Wang, T. F. Lan, H. F. Lee, C. H. Chen, V. Walia, and Q. C. Sung, 2004: composition and exhalation flux of gases from mud volcanoes in Taiwan. Environ. Geol., 46, 1003-1011.

Yang, T. F., P. C. Chuang, S. Lin, J. C. Chen, Y. Wang, and S. H. Chung, 2006: Methane venting in gas hydrate potential area offshore of SW Taiwan: evidence of gas analysis of water column samples. Terr. Atmos. Ocean. Sci., 17, 933-950.

Horng, C. S., and K. H. Chen, 2006: Complicated magnetic mineral assemblages in marine sediments offshore of southwestern Taiwan: possible influence of methane flux on the early diagenetic process. Terr. Atmos. Ocean. Sci., 17, 1009-1026. 